Bogumil Terminski, "Realizing the Right to Health of Undocumented Immigrants in Europe: Legal and Social Challenges", Proceedings of the 13th World Congress on Public Health, April 23-27 2012, Monduzzi Editore, Bologna, 2013, pp. 463-479.

\title{
Realizing the Right to Health of Undocumented Immigrants in Europe: Legal and Social Challenges
}

\author{
Bogumil Terminski
}

University of Warsaw

\begin{abstract}
The subject of the analysis presented in this article is the legal context and political debates regarding access of undocumented migrants to health care assistance and institutions of public health. Consequences of non-regulated legal status significantly impair or even deny illegal migrants the most basic access to medical care. The main condition of entitlement to specialized medical care is legal residence within a state in accordance with its legal provisions. Fearing a growth in illegal migration and increased expenditure, EU countries are not interested in extending social benefits to irregular migrants. Fearing deportation, dismissal from work and the enormous costs of private health care, they usually do not ask for professional medical assistance. By analyzing the most important health risks for migrants the author has also highlighted the current legal and political debates on this issue. Lawful residence based on migration status and rules which governing the welfare state must be coordinated with migrants' access to health care on the basis of universality and non-discrimination. In recent years we have seen a growing tendency in Europe to restrict access to health care for undocumented migrants and reinforce the relationship between access to health care institutions and immigration control policies. In many EU countries such as Sweden and Denmark, the right of undocumented migrants to free emergency care and more advanced health care is restricted and may be subject to payment. Examining international treaties and explanatory documents from the Council of Europe and the United Nations, I try to analyze relevant international laws affecting several groups of undocumented migrants concerning the right to health and access to health care institutions. This article also highlights activities undertaken in recent years by NGOs with the aim of establishing access to health for undocumented migrants in EU countries and placing this issue on the international agenda.
\end{abstract}

\section{Introduction}

Illegal (irregular, undocumented) migration is nowadays not only a social problem and a challenge to national and regional security but also a subject of debate for experts in the field of public health. According to WHO reports, illegal migrants are one of the groups most at risk of health problems. This fact is connected to two basic circumstances: their irregular legal status and the consequences of economic and social marginalization (including limited scope for employment). Undocumented legal status means that illegal migrants often do not have proper access to more specialized medical care. Generally, this deficiency is a consequence of the illegality of residence, illegal work, undocumented or irregular situation and finally the lack of health and social insurance, alongside other forms of conflict with the law. Social rights and privileges of illegal immigrants within EU territory may therefore not be commensurate with or even close to those of citizens, EU member state citizens or foreign residents residing within EU territory legally. The first factor in the exclusion of migrants from access to health assistance is thus domestic law based on the principle of legality of stay. No country can afford to extend social benefits to those who break the law, as that could be a pull factor for illegal migration and impair the ideal of the state under the rule of law. Social benefits for illegal migrants are usually limited to basic medical assistance in emergency situations. Such support is a consequence of the institutionalized development of international human rights law and the principle of humanitarianism.

Many migrants in fear of expulsion or dismissal are afraid to use even the basic forms of 
health care. Their financial situation means that they cannot afford to use private medical care. Another factor affecting health risks lies in the consequences of the migration process and the social exclusion of illegal immigrants in their new place of residence. Many health problems affecting asylum seekers, and undocumented immigrants are associated with poverty and deprivation. The current dynamics of external migration to the EU incorporate many risks to health: epidemic diseases, difficulties related to pregnancy, children's illnesses, the situation of older undocumented migrants and psychological problems. Illegal immigrants are mentioned as a category of people particularly vulnerable to HIV and AIDS. This problem is especially visible in South Asia, but even in Europe it is affecting a significant proportion of illegal immigrants. Furthermore, in the new place of residence, the migrants are exposed to various forms of exclusion leading to the deterioration of their health. In most cases they are forced to take the low-paid jobs that citizens and lawful residents are not interested in. In literature they are referred to as the 3D (Dirty, Dangerous and Demanding). This situation often leads to accidents at work and a death toll which is difficult to estimate accurately. According to representatives of non-governmental organizations, as many as hundreds of undocumented immigrants are killed each year in Western Europe following illegal employment. The problem is however much less visible than in China, e.g. during preparations for the Summer Olympic Games in Beijing in 2008. Health problems are also aggravated by immigrants' housing difficulties and poor sanitary facilities. The fact of illegal employment enhances the already huge asymmetry between migrant workers (EU citizens) and undocumented migrants. After doing their jobs, they acquire no health benefits. Unregistered performance of work prevents national institutions from monitoring the health situation of the employees. The language barrier often prevents migrants from knowing their rights regarding access to medical care or costs of medical services.

The possibility of irregular migrants' access to health care institutions in most European countries is limited to emergency situations only. Primary health care institutions are obliged to provide emergency care without discrimination. In the press, from time to time, one can find information on medical assistance to victims of trafficking, worn-out boat people, or illegal migrants arrested while trying to cross the border. Much more difficult for illegal migrants is gaining access to long-term therapy for chronic diseases (such as.cancerous, nephrological, surgical, or orthopaedic diseases) that require advanced medical treatment, or even to medical care during pregnancy. In Belgium, France, Italy and Spain, irregular migrants' access to more advanced medical care is possible under certain conditions. In France, undocumented migrants can access health care free of charge (with some exceptions) under a system called "Aide Médicale État". In Belgium, illegal migrants can obtain urgent medical assistance (Aide Médicale Urgente) free of charge. There are only some exceptions regarding payment for prosthetic devices and some categories of medicine. In Italy, undocumented migrants have access to wide health care protection through a specific system (called STP - Temporarily Present Foreigners). Undocumented migrants in this country are normally requested to pay a symbolic amount of money (so-called ticketi) for access to health care. In Denmark undocumented migrants have a right only to basic medical care, and additional medical treatments may be subject to payment. In Sweden undocumented migrants have the right to basic medical care only, but an exception is made for asylum-seeking children, who have similar rights to those of Swedish citizens. In the Netherlands, undocumented migrants have access to primary, secondary and even tertiary health care (see Biswas et al., 2012). However, according to the HUMA Network report of 2009, "Undocumented migrants in Netherlands can only access care considered by doctors on a case by case basis as "medically necessary"'. Very often the victims of difficult access to medical care are children and pregnant women. Problems of this kind are not as visible in Europe as in other parts of the world, especially in developing countries. Medical facilities in Europe put strong emphasis on emergency assistance provided to under-age persons without any discrimination based on origin and legality of residence. However, there remains a problem of illegal immigrants' fear of the consequences of using the public health system (e.g in Germany). The problems mentioned here to a greater or lesser extent affect more than 4 million illegal immigrants in Western Europe. According to the Global Commission on International 
Migration (2005), between 4.5 to 8 million undocumented migrants live in the European Union, which is about $1.5 \%$ to $1.6 \%$ of Europe's population. One should point out, however, that in no highly developed country do illegal migrants have full access to all medical services. In European health care institutions, which are based on compulsory insurance for all citizens, the situation appears somewhat better than in the United States. Here there are important anti-discrimination rules expressed in national legislation and EU Community Law regulations.

The access of undocumented migrants to health care has become an object of increasing attention and activity on the part of both international and non-governmental organizations. The legislation of EU member states is characterized by differences in approach to this problem and huge disparities among the various EU members. That is why in recent years many studies have appeared comparing the access to health care for undocumented migrants in different countries. In the next section of the article I shall try to describe the conclusions of several reports on this topic issued recently. The first cross-sectional analysis of undocumented migrants' access to health care in eleven EU countries was the 2007 study published by Médecins du Monde European Observatory of Access to Health Care ${ }^{1}$. According to this study, undocumented migrants usually do not have access to health care even if they are entitled to it. The report took into account the legal regulations and practical access to health care institutions in eleven countries (Belgium, Switzerland, Germany, Greece, Spain, France, Italy, Netherlands, Portugal, Sweden, United Kingdom). In four of these countries (Greece, Germany, Switzerland, Sweden), access to health care is restricted to emergency care only. In six of the countries analyzed, the legal regulations provide partial coverage of health care costs for undocumented migrants unable to pay it. The last analyzed country (the United Kingdom) is characterized by a very specific system.

In 2007, the Platform for International Cooperation on Undocumented Migrants (PICUM) published a comparative study on the legal and practical aspects of access of undocumented migrants to health care within the context of human rights in ten EU states: Belgium, France, Germany, Italy, Malta, the Netherlands, Spain, Portugal, Sweden and the UK. Two years later this study was updated and published once more (Access to Healthcare for Undocumented Migrants and Asylum Seekers in 10 EU Countries: Law and Practice). The following year the publication was expanded with the results of research undertaken in six new EU states (Cyprus, Czech Republic, Malta, Poland, Romania and Slovenia) and published under the title "Are undocumented migrants and asylum seekers entitled to access health care in the EU? A comparative overview in 16 countries". In 2012, the HUMA Network published a new report entitled Access to Healthcare and Living Conditions of Asylum Seekers and Undocumented Migrants in Cyprus, Malta, Poland and Romania. The main goal of this publication was to present the precarious situation and health problems facing the two most vulnerable groups of aliens living in Europe: asylum seekers and undocumented migrants in Cyprus, Malta, Poland and Romania. This report provides expert knowledge of legal regulations concerning access to health care for illegal migrants, asylum seekers and their children in these states, as well as comprehensive information about living conditions and practical difficulties of access to health care. All these countries joined the EU recently and are located on its external borders; hence they are experiencing quite similar problems in the context of undocumented migration.

\section{Political debates and the implementation of the right to health and access of illegal immigrants to health care in selected European countries}

The situation of illegal immigrants is only one minor component of the challenges facing the health sector in EU countries. The ageing population, combined with the economic crisis and the increase in the price of medical services, means that it is increasingly difficult to provide medical assistance to all needy groups out of declining tax revenues. Wealthy EU countries are not interested in changing the existing rules on access to health care institutions, which are based on the legal situation (migration status), and available insurance. The access of undocumented/illegal migrants

1 Chauvin, P., Parizot, I. and N. Simmonot, Access to Health Care for Undocumented Migrants in 11 European Countries, Médecins du Monde European Observatory of Access to Health Care, 2008. 
and asylum seekers to health care illustrates the clash between humanitarianism and nondiscrimination, on the one hand, and the particular economic interests related to the principle of legality of residence, on the other. In many EU states, irregular migrants have only a narrow range of medical assistance available (assistance in the event of threats to life, accidents, pregnancy and childbirth). Only legal residence in the state's territory and fulfilment of certain requirements (migration status, health insurance) give rise to obligations in respect of more specific forms of medical treatment. The purpose of such policies on medical care is to protect EU countries against excessive illegal immigration, people overstaying permitted time limits, and an increase in demanding attitudes on the part of immigrants. Research conducted recently by the government of Sweden indicated that easy access to medical care is a factor contributing to migration and renewal of residence in that country.

Principles of illegal migrants' access to health care in EU countries are diverse. The recently conducted EFRA research shows that, in six out of ten EU countries, irregular migrants do not have any free access to health care except in life-threatening cases. The prepared report shows that the greatest potential access to health care by illegal migrants is found in Belgium, France, Spain and Italy. Undocumented migrants in Belgium are granted free access to urgent medical care. Illegal migrants also enjoy the widest access to free medicine in these countries. Illegal migrants' access to health care often depends on its cost. Scandinavian countries, which have well-developed principles of social policy for its own citizens, are slowly moving away from far-reaching assistance to migrants. In Germany, irregular immigrants have fairly limited access to health care, similar to that available to asylum seekers. According to the HUMA report of 2009, undocumented migrants and asylum seekers in Germany enjoy free access to medical care in the situation of "serious illness or acute pain" as well as "everything necessary for recovery, improvement or relief of illnesses and their consequences" (including, inter alia, ante/post-natal care and AIDS/HIV treatment) ${ }^{2}$. In Sweden, Hungary and Greece, illegal migrants are forced to cover the cost of basic medical care. The widest scope for migrants' access to medical care nowadays is found in Spain, which is considered one of the most favorable countries in regard to provision of health care to undocumented aliens. The situation is markedly different on the Scandinavian peninsula. Countries applying the rules of the welfare state to its own citizens are not interested in extending social benefits to illegal immigrants. Irregular immigrants in Sweden have to pay much more for medicine than ordinary citizens and tourists. According to the Act of the Greek Parliament 3385/2005, "no public service should be provided to anyone who illegally resides in the country". It also prescribes that such service should be provided "only in emergency situations and in case of children". It is worth mentioning that, according to some sources, over 90 percent of undocumented immigrants enter Europe through Greece. Currently Greek maternity hospitals are about to collapse due to the costs of the undocumented immigrants' baby boom. According to the Greek health minister, a "huge influx of mainly African and Asian migrants into Greece in 2010-2011 posed heightened risks to public health, as well as putting massive strain on the country's overburdened state health services"3. Human trafficking is the main reason Greece has seen a "significant" increase in recorded HIV infections in 2011, many of which concerned women who had been brought into the country illegally and forced to work as prostitutes.

The problem of access to health care institutions should be considered in the context of the dynamics of illegal migration and migration policies of individual EU countries. For many countries, the only way to reduce costs is to block illegal migration and to create international cooperation in this area. Spain, Italy and Malta are the countries particularly at risk of large-scale migrations from Africa. To avoid the need to finance the health care of migrants, they pay close attention to the EU's external borders. These states play a significant role in the functioning of the FRONTEX agency, set up within EU structures in 2005, and initiate cooperation on the prevention

2 Access to Health care for Undocumented Migrants and Asylum Seekers. Law and Practice (Germany), HUMA Network 2009.

3 http://greece.greekreporter.com/2011/12/27/greek-maternity-hospitals-about-to-collapse-due-to-immigrants-babyboom-costs/ 
of transmission of epidemic diseases. Let us mention here at least several exoduses of migrants from Tunisia and Libya to the Italian island of Lampedusa. Allowing refugees to stay in Italy would burden this country with high costs in social and medical assistance. Countries with restrictive immigration policies (Sweden, Norway) are introducing limitations on access to health care. Restriction of access to highly specialized medical services is a mechanism of immigration control and prevention of illegal migration. But contrary to appearances, the level of health care is not a major factor in attracting people to a given territory; the level of national health care institutions is therefore not a primary pull factor for undocumented mmigrants.

Within the fora of the European institutions one can observe a debate on the lack of access to health care dependent on migrant status. International documents indeed state the right of everyone to adequate health care regardless of location or origin. This term, however, leaves too much freedom of interpretation (ranging from access to basic medical care to the use of expensive longterm cancer therapies by migrants). Further neglect of the problem can lead to significant disparities between the health of European Union citizens and that of illegal immigrants, therefore to discrimination in one of the most fundamental human rights (the right to life). Opponents of such reasoning argue that the demand for advanced health services will always surpass the supply. Recognition of the right of illegal migrants to health cannot be equated with equal access to health care. According to many, illegal/undocumented immigrants put themselves beyond the pale of society and forfeit their own rights by breaking immigration laws. But defining lack of access to health services as a penalty for violation of immigration laws is completely incompatible with contemporary human rights standards. According to others, if in the United States access to health care is not an entitlement for all citizens, maybe there is nothing wrong with maintaining the status quo in the EU. The problem turns out to be that, given enormous progress in medicine and the potential extension of the disparities between benefits available to different social categories of people, practices which a decade ago were normal soon could pass for human rights violations. The increase in a society's wealth should be accompanied by the development of instruments of social support for the most needy and vulnerable groups. The wish to reduce costs and concern about the health of the country's own citizens cannot justify the creation of solutions that lead to even greater marginalization of illegal immigrants.

\section{The implementation of the right to health of illegal immigrants. Institutional and legal framework}

The right to health was first introduced in provisions of of the World Health Organization (WHO) constitution of 1946 which states that "the enjoyment of the highest attainable standard of health is one of the fundamental rights of every human being without distinction of race, religion, political belief, economic or social condition". The conctitution preamble defines health as "a state of complete physical, mental and social well-being and not merely the absence of disease or infirmity".

The Universal Declaration of Human Rights adopted in 1948 mentioned health as part of the right to an adequate standard of living (Art. 25). According to this article, "everyone has the right to a standard of living adequate for the health and well-being of himself and of his family, including food, clothing, housing and medical care and necessary social services, and the right to security in the event of unemployment, sickness, disability, widowhood, old age or other lack of livelihood in circumstances beyond his control". Essential for the achievement of access to health care are the provisions of Article 12 of the United Nations International Covenant on Economic, Social and Cultural Rights (ICESCR). According to this document, states recognize "the right to the enjoyment of the highest attainable standard of physical and mental health" by "refraining from denying or limiting equal access for all persons, including prisoners or detainees, minorities, asylum seekers and illegal migrants to preventive, curative and palliative health services; abstaining from 
enforcing discriminatory practices as a state policy". The provisions apply to all persons residing within the borders of a country, and thus to migrant workers and immigrants in an irregular situation. Despite the idea expressed for example in Article 8 (1) (c) of the 1985 "Declaration of the human rights of individuals who are not nationals of the country in which they live" regarding the necessity of lawful residence in the state, access to health care is a right of all migrants regardless of migration status (CESCR, General Comment No.14: The Right to the highest attainable standard of health, 2004). According to the CESR comment of 2008: "all persons, irrespective of their nationality, residency or immigration status, are entitled to primary and emergency medical care" (CESR General Comments, 27th May 2008). The ILO Convention No. 97, signed in 1975, is the first universal document on irregular migration, and formulates expanded access to health care. Due to the limited number of ratifications, its provisions are virtually meaningless. The same applies to provisions of the International Convention on the Protection of the Rights of All Migrant Workers and Members of Their Families (CMW), adopted in 1990 and entering into force in 2003. Because of the imprecise and far-fetched deliberations contained in the provisions of these documents, all EU Member States oppose them. One of the obstacles to the ratification of ICRMW by the EU member states are provisions of its article 24 which states that "migrant workers shall enjoy treatment not less favourable than that which applies to nationals of the State of employment in respect of remuneration" and "states Parties shall take all appropriate measures to ensure that migrant workers are not deprived of any rights derived from this principle by reason of any irregularity in their stay or employment. In particular, employers shall not be relieved of any legal or contractual obligations, nor shall their obligations be limited in any manner by reason of such irregularity". Article 24 of the Convention on the Rights of the Child (CRC) obliges state parties to provide children with full access to medical care and assistance for their mothers before and after childbirth. The references to access to health can also be found in the texts of CERD and CEDAW (provisions of the latter of these documents can be interpreted as referring also to migrant women in an irregular situation). One should also mention the activities of the Special Rapporteur on the right to health, established in 2002.

The provisions of European legislation on illegal immigrants' access to health care are much more precise and restrictive. Legality of residence is the primary source of differentiation between the legal situation of regular and irregular migrants (see Article 13 (4) of the European Social Charter). Such an approach to the subject was confirmed earlier in the European Convention on Social and Medical Assistance, signed in Paris on 11th December 1953. The human rights protection system of the Council of Europe, therefore, does not guarantee proper access to health care institutions for irregular migrants.

The European Union is supposed to promote health systems based on principles of solidarity, access to good quality care, universality and equity. However, Article 35 of the Charter of Fundamental Rights of the European Union leaves the establishment of rules for access to health care to national legislators. As the document states "everyone has the right of access to preventive health care and the right to benefit from medical treatment under the conditions established by national laws and practices. A high level of human health protection shall be ensured in the definition and implementation of all the Union's policies and activities". By analyzing the activities of EU institutions, one can nevertheless find support for practices aimed at improving access of irregular migrants to basic health care. Access to health care for asylum seekers and undocumented migrants is directly linked to cooperation with the fight against illegal migration. The Treaty of Amsterdam, which entered into force in 1999, has played a significant role in the intensification of debate over the scope of access of undocumented migrants to health care. Let us, for example, mention Article 14 of the EU Returns Directive. In March 2011 the European Parliament adopted a resolution entitled "Reducing health inequalities in the EU". It recommends that all Member States take action to support the health of undocumented migrants, especially pregnant women and children. Implementation of the provisions of the declaration can be a real breakthrough in the process of broad implementation of access to health care for migrants in irregular situations. In the 
2009 communication on "Solidarity in Health: Reducing Health Inequalities in the EU", the European Commission has chosen to exclude groups of migrants suffering because of "discrimination, stigmatisation and barriers to accessing health and other services". Reduction in the problems mentioned here, however, will depend primarily on the activity and will of national administrations, rather than EU institutions. It is also worth to mention article 14 of the European Union Return Directive which provides "emergency healthcare and essential treatment of illnesses" must be provided to irregular migrants during the period given for their involuntary departure and when removal has been postponed.

The table below shows the main human right provisions relating to right to health and access to healthcare.

\begin{tabular}{|c|c|c|}
\hline Instrument & $\begin{array}{c}\text { Date of } \\
\text { establishment }\end{array}$ & Provisions relating to healthcare \\
\hline UDHR [article $25(1)]$ & 1948 & $\begin{array}{l}\text { "right to a standard of living adequate for the } \\
\text { health and well-being of himself and of his } \\
\text { family, including }[\ldots] \text { medical care }[\ldots] "\end{array}$ \\
\hline ICESCR [article 12] & 1966 & $\begin{array}{l}\text { "highest attainable standard of physical and } \\
\text { mental health"; General Comments No. } 3 \text { and No. } 14 \text { provides } \\
\text { the access to "essential primary health care" as a minimum. }\end{array}$ \\
\hline CEDAW [article 12 (2)] & 1979 & $\begin{array}{l}\text { women grant "appropriate services in connection } \\
\text { with pregnancy, confinement and the post-natal } \\
\text { period, granting free services where necessary, } \\
\text { as well as adequate nutrition during pregnancy } \\
\text { and lactation." }\end{array}$ \\
\hline ICERD [article 5 (e) (iv)] & 1965 & $\begin{array}{l}\text { eliminate racial discrimination as regards the } \\
\text { "right to public health, medical care, social } \\
\text { security and social services" }\end{array}$ \\
\hline CRC [article 24] & 1989 & $\begin{array}{l}\text { "states Parties recognize the right of the child to the } \\
\text { enjoyment of the highest attainable standard of health and to } \\
\text { facilities for the treatment of illness and rehabilitation of } \\
\text { health. States Parties shall strive to ensure that no child is } \\
\text { deprived of his or her right of access to such health care } \\
\text { services" }\end{array}$ \\
\hline ICRMW [article 28] & 1990 & $\begin{array}{l}\text { "right to receive any medical care that is urgently } \\
\text { required for the preservation of their life or the } \\
\text { avoidance of irreparable harm to their health }[\ldots] \text { " }\end{array}$ \\
\hline $\mathrm{ESC}$ & $\begin{array}{c}1961 \text { (revised in } \\
\text { 1996) }\end{array}$ & $\begin{array}{l}\text { "to apply the provisions of Article } 13 \text { (1) on an } \\
\text { equal footing with nationals granting effective } \\
\text { exercise of the right to social and medical } \\
\text { assistance for persons without adequate } \\
\text { resources" }\end{array}$ \\
\hline
\end{tabular}

\section{Conclusions: The political and legal perspectives on increasing access to health care for irregular migrants}

Health care in the era of globalization is an increasingly expensive and inaccessible resource. The economic crisis and ageing of societies means that rich countries have a growing problem with the implementation of this right for its own nationals. The dynamics of migration movements are shaping not just the prospects of finding work but also the well-functioning institutions of social support and access to health care on a broader scale. In times of unemployment, financial insecurity, and crisis, social and health care are among the fundamental needs of society. The group of undocumented migrants in Europe, estimated at several millions, is interested in proper access to 
national health care institutions. The extension of such benefits to all persons residing in the territory of the state is not only unfeasible but also unfair. Yet illegal migrants should have access to basic health care without fear of worsening their legal status or expulsion. There should be a slow expansion of access to health care (secondary and tertiary health care) based on factors other than migration status. One should also consider exact definitions of such terms as "primary medical care", "secondary medical care", "basic medical care" and "urgent medical care" by the national institutions. Such definitions can provide a point of reference for national institutions and the creation of a coherent system of health assistance to illegal immigrants. Difficult access to health care needs to be analyzed as one of the problems of illegal immigrants. These include legal conditions, economic marginalization and social alienation. Efforts to help illegal immigrants will always be accompanied by measures to minimize this process. Combatting illegal immigration is undertaken not only to protect the native labor market but also to prevent pathologies such as human trafficking, epidemic threats, health risks and deterioration of the conditions of people in a new country. Public health professionals must play a significant role in the analysis of these processes.

The increasing number of undocumented migrants may cause a significant deterioration in the health of citizens of their country of residence. It often also leads to more difficult access to health care institutions for the country's citizens. Undocumented migrants are considered particularly vulnerable to health threats, especially epidemic diseases. Their uncontrolled influx to some EU countries may even lead to an increase in HIV infections. In times of financial crisis and reduced expenditure, access to medical treatment is becoming increasingly difficult even for a state's citizens or immigrants residing in its territory in accordance with the law. Today in Greece the need to provide medical assistance to some groups of undocumented migrants hampers its citizens' access to certain medical services. There is thus a need for detailed regulations concerning undocumented migrants' access to specific medical benefits, resting on the principles of human rights and complying with current humanitarian standards.

At present it is difficult to unambiguously determine the prospects for greater access of irregular migrants to health care in EU countries. This problem engenders strong political differences, while the lack of regulations within EU Community Law creates wide variation in support mechanisms for immigrants. Lack of broad access to health care institutions continues to be treated as a mechanism for reducing illegal immigration (a view which is not entirely well-grounded in fact). The European Commission and the European Parliament are undertaking limited activity in terms of equal opportunities in access to health. The provisions mentioned are mostly limited to excluded groups (homeless people, minorities) and migrant workers within the common European labor market (EU citizens). Political activities in this field should not be based only on economic interests and anti-migration efforts but also should protect people already affected by problems that stem from increasing social exclusion. Even states with anti-migration policies cannot afford to maximize the health problems of people already experiencing poverty, ghettoization, illegal employment, and an unregulated legal situation. It is difficult to determine precisely whether access to health care is a right of every human being and an outgrowth of humanitarian principles, or a provision due only to those paying taxes and generating tax revenues. One should also consider linking medical assistance provided to migrants with an adjustment of their legal status; nongovernmental organizations and the local authorities of some cities have begun to take such measures.

\section{Non-governmental (NGO) sector cooperation in establishing access of undocumented migrants to health care institutions}

European Union institutions and EU common law leave member states a large degree of flexibility in terms of the level of access of undocumented migrants and asylum seekers to health care. The primary mechanism of support for undocumented migrants in terms of access to medical care is national legislation. This is because internal law regulates the scope of undocumented migrants' free 
access to the public health services. In the situation of very limited access of migrants to primary health care, NGOs turn out to be very important sources of practical support and assistance to migrants. In the following section of this article I shall pay attention to the activities of nongovernmental organizations in helping undocumented migrants secure access to health care. The NGO sector performs several basic functions in providing access to health care for this group. The most fundamental of these functions consists of direct aid to undocumented migrants, especially those most vulnerable to health problems such as children and pregnant women. In many European countries, non-governmental organizations hold special clinics for undocumented migrants. Just as often, associations of this kind help migrants to pay for the cost of access to a doctor. A significant obstacle to access to health care for irregular migrants is the language barrier and fear of being reported to the immigration authorities. Many associations help by consulting on undocumented migrants with health care institutions. The activities of many associations are further focused on assisting in the regularization of migration status or meeting formal legal requirements, allowing undocumented migrants access to medical care at least in urgent situations. An important area of activity of non-governmental organizations is the initiation of research and international cooperation in this particular field. Médecins Sans Frontières, PICUM and HUMA publications are important sources of knowledge on the extent of asylum seekers' and undocumented migrants' access to health care. These institutions also lobby European organizations to promote relevant regulations allowing better access to health care for undocumented migrants in the EU member states. One particular area of activity of many NGOs is the elimination of problems in accessing health care for the children of undocumented migrants. They should not be held responsible for the illegal situation of their parents.

Among the most important activities carried out by NGOs in support of undocumented migrants' access to health care, we can mention:

- Practical aid in obtaining access to health care for the most vulnerable groups of undocumented migrants and asylum seekers. Among them we can mention pregnant women, children, and people suffering from chronic or serious illnesses requiring immediate medical attention.

- Informing undocumented migrants of their rights. Non-governmental organizations also undertake practical activity such as advocacy and support in the regulation of the legal status of undocumented migrants. An important tool for achieving this goal is information campaigns aimed at undocumented migrants.

- Information activities, research, and international cooperation. Of particular importance is the focus on national authorities with a view to enhancing the right of undocumented migrants to access to health assistance.

In the next part of the article I shall draw attention to the activity of several NGOs working to promote access to health care for undocumented migrants in Europe. Associations of this kind are present in almost every EU country. Most deal with countries beyond the EU's external borders, or those faced with a large population of undocumented migrants. We can observe many associations of this kind in Spain, Italy and Greece. Their activity appears to be particularly crucial in countries where undocumented migrants have limited access to health care and legal procedures are difficult to navigate. Helping undocumented migrants with access to health care is an objective both of international organizations characterized by general and extended humanitarian profiles (Caritas Internationalis, Human Rights Watch) and of national or regional associations specializing in this issue (Amber-Med Austria, Centre for The Health of Foreign Family). There has turned out to be a very important increase in the number of such institutions in the new EU member states, where the civil sector is not yet well developed. Many of them, such as Poland and Romania, are located on the EU's external borders and struggle with a large influx of undocumented migrants along with human traffickers and their victims. Also important is the extension of activities aimed at informing EU citizens about the rights of undocumented migrants in their countries. Finally, many 
international platforms and research networks, such as the HUMA Network, PICUM, and Médecins du Monde, are operating in EU countries to publicize this issue or give practical support. In the next section of this article I shall analyze a few selected organizations that undertake practical action or promote access to health care for undocumented migrants.

The Platform for International Cooperation on Undocumented Migrants (PICUM) is a nongovernmental organization that aims to cultivate respect for the human rights of undocumented migrants in Europe and to give them practical protection. This goal is accomplished through advocacy, awareness raising and capacity-building activities. The initiative to establish PICUM was fulfilled in the late nineties thanks to the efforts of non-governmental organizations from Belgium, the Netherlands and Germany. Among the most important areas of PICUM`s practical activities we can mention: 1. Monitoring and reporting (improving the understanding of human rights issues affecting undocumented migrants in Europe), 2. Capacity building (developing the capacities of NGOs and other social actors involved in protecting undocumented migrants and preventing discrimination against them), 3. Advocacy (promotion of appropriate legal safeguards and mechanisms for the integration of undocumented migrants within national and European institutions), 4. Awareness raising (promotion of good practices concerning the human rights of undocumented migrants among relevant organizations and the broader public), 5. Global action on international migration (contributing to the improvement of knowledge and dialogue on international migration issues within the UN system agencies, other international institutions and the NGO sector $)^{4}$. Currently PICUM has nearly 90 ordinary members and 90 affiliated members in approximately 20 countries all over Europe (2007). Activities fostering access to health care for undocumented migrants and the promotion of this issue have been on PICUM`s agenda for many years. In 2007 the organization issued a publication entitled Access to Health Care for Undocumented Migrants in Europe.

The Health for Undocumented Migrants and Asylum Seekers (HUMA) Network, a project established by Médecins du Monde (Doctors of the World), and composed of 16 partners in 16 EU countries, promoted access to health care for asylum seekers and undocumented migrants on an equal basis with nationals within the EU from 2008 to 2011. Its key activities were: 1. Raising awareness of the problem of aliens' access to health care and mobilizing health professionals, 2 . Developing activities to guarantee effective access to health care for all asylum seekers and undocumented migrants, 3. Taking action to secure permission/authorization to stay for all undocumented migrants and asylum seekers with serious health problems, 4 . Undertaking actions to develop effective access to health care for foreigners in waiting areas/detention centres, etc. Médecins du Monde (MDM) is a French non-governmental organization established in 1990. Since that time the organization has engaged in many activities to improve the situation and access to health care of undocumented migrants, including those in Europe. The organization is a coordinator of a three-year programme entitled European advocacy project to improve access to health care for undocumented migrants in Europe (2012-2015). The aim of this programme is to "ensure the equal rights and effective access to health care of undocumented migrants, which will involve carrying out a global advocacy strategy towards EU and national institutions and policy-makers, and communicating information based on evidence-based reports" . The main goals of the programme are: 1. To provide access to health care and protection from deportation for seriously ill undocumented migrants in the EU who will be unable to obtain crucial medical treatment in their country of origin, 2. To promote changes in EU policies on measles, HIV, hepatitis and tuberculosis in order to ensure undocumented migrants' access to prevention and treatment of these diseases, 3 . To guarantee access to health care coverage for everyone living in the EU on an equal basis, especially for the most vulnerable groups such as undocumented migrants.

Let us now consider the activities of smaller national organizations giving undocumented

4Access to Health Care for Undocumented Migrants in Europe, PICUM, Brussels, 2007.

5 http://www.epim.info/medecins-du-monde-international-network/ 
migrants practical help in gaining access to health care. Caritas-Marienambulanz is a department of Caritas Austria which has been in operation since 1999. The organization offers "low-threshold general medical primary health care for all people without health insurance (natives and foreigners), illegal migrants living in Austria and uninsured people (natives and foreigners), who cannot overcome the barriers in access to the public health care system". Medimmigrant is a Belgian NGO located in Brussels. Its aim is to guarantee access to health care for undocumented migrants living in the region of Brussels. Medimmigrant combines practical casework with structural actions related to "access to health care and to obtaining (or maintaining) a residence permit for medical reasons". Another Belgian NGO active in this particular field is Oriëntatiepunt Gezondheidszorg Oost-Vlaanderen (Support Point Health Care East Flanders). The aim of this institution is to increase access to health care institutions for undocumented migrants and asylum seekers in East Flanders. It is also worth mentioning the Italian organization Ambulatorio Medico Popolare, which provides health care to all needy people. Associazione Santa Chiara is a Roma-based organization providing health care and legal assistance to Roma people (mainly from Macedonia) living in a Roma camp outside Rome. Poliambulatorio S. Chiara-Caritas per Cittadini Extracomunitari is a local health care clinic located in Palermo that provides basic medical assistance to undocumented migrants in that city. I should also mention the Italian NGO called NAGA, based in Milan, which provides social assistance to and promotes the rights of temporarily resident migrants, undocumented migrants and refugees. COMEDE (France) is a Paris-based organization promoting access to health care for asylum seekers, rejected asylum seekers and any foreigners who have difficulties in accessing the health care system, as well as providing free medical and psychological care. It is also worth mentioning the NGO PHAROS based in The Hague. The main purpose of this organization of health experts is to provide information on access to health care for undocumented migrants and asylum seekers.

\section{References:}

Biswas D., Toebes B., Hjern A., Ascher H., Norredam M., "Access to health care for undocumented migrants from a human rights perspective: A comparative study of Denmark, Sweden, and the Netherlands", Health and Human Rights. An International Journal, Vol. 14, No. 2, 2012.

Björngren Cuadra, Carin, "Right of access to health care for undocumented migrants in EU: a comparative study of national policies", European Journal of Public Health, Vol. 22, No. 2, 2012, pp. 267-271.

Chetail V., Giacca G., "Who Cares? The Right to Health of Migrants" [in] M. Robinson, A. Clapham (eds.), Realizing The Right to Health, Zürich, Rüffer\&Rub, pp. 224-234, 2009.

Dwyer J., "Illegal Immigrants, Health Care, and Social Responsibility", Hasting Center Report, Vol. 34, no. 5, pp. 34-42, 2004.

FRA, Migrants in an irregular situation: Access to healthcare in 10 European Union Member States, Vienna, European Union Agency for Fundamental Rights, 2011.

Romero-Ortuno R., "Access to health care for illegal immigrants in the EU: should we be concerned?", European Journal of Health Law, Vol. 11, pp. 245-272, 2004.

Terminski B., "Europeizacja Przestrzenni Polityki Społecznej: W Poszukiwaniu Regionalnego Paradygmatu Rozwoju", Auxilium Sociale Novum, Vol. 1-4, 2010, pp. 45-60.

Termiński B., Międzynarodowa ochrona pracowników migrujacych. Geneza, instytucje, oddziaływanie, Warszawa, Wydawnictwo Uniwersytetu Warszawskiego, 2011.

Terminski B., "The right to adequate housing in international human rights law: Polish transformation experiences", Revista Latinoamericana de Derechos Humanos, Vol. 22, No. 2, 2011, pp. 219-241.

Terminski B.(ed.), Selected Bibliography on Human Right to Health, Research Paper, University of 
Geneva, January 2013.

Willem S.S., "Do "Illegal” Im/migrants Have a Right to Health? Engaging Ethical Theory as Social Practice at a Tel Aviv Open Clinic", Medcal Anthropology Quarterly, Vol. 25, Issue 3, pp. 303-330, 2011.

\section{List of abbreviations:}

CEDAW-Convention on the Elimination of All Forms of Discrimination against Women

CERD-Committee on the Elimination of Racial Discrimination

CMW- International Convention on the Protection of the. Rights of All Migrant Workers and Members of Their Families

COE- Council of Europe

CRC-Convention on the Rights of the Child

ICESCR-International Covenant on Economic, Social and Cultural Rights

ECHR- European Convention of Human Rights

EMHRN-Euro-Mediterranean Human Rights Network

EPIM- European Programme for Integration and Migration

FRONTEX-European Agency for the Management of Operational Cooperation at the External Borders of the Member States of the European Union

GCIM- Global Commission on International Migration

GISTI-Groupe d'information et de soutien des immigrés

HUMA- Health for Undocumented Migrants and Asylum Seekers Network

MRI-Migrants Rights International

NEF-Network of European Foundations

NGO- Non-governmental Organization

PICUM-Platform for International Cooperation on Undocumented Migrants

SOPEMI-Systeme d'Observation Permanente sur les Migrations (International Migration Outlook)

UDHR- Universal Declaration of Human Rights

UDM- Undocumented Migrants

UNHCR-United Nations High Commissioner for Refugees

WHO-World Health Organization 